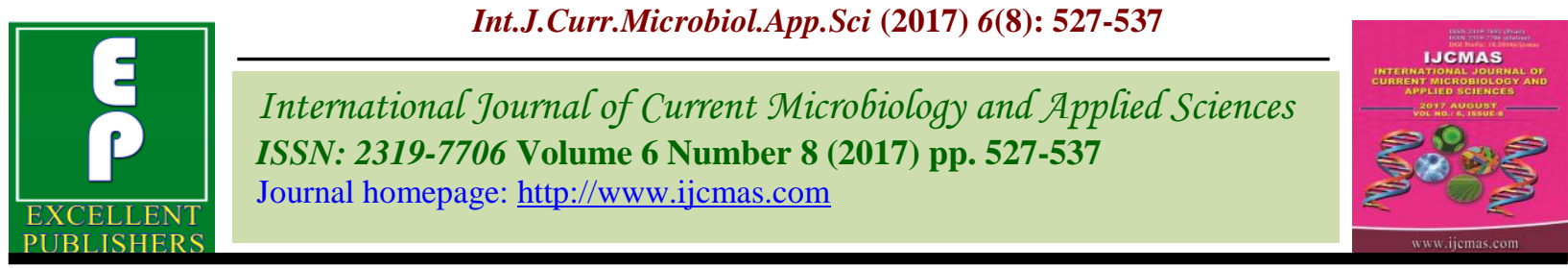

Original Research Article

https://doi.org/10.20546/ijcmas.2017.608.068

\title{
Effect of Land Configuration, Irrigation and INM on Quality, Nutrient Content and Uptake of Indian Bean (var. GNIB-21)
}

\author{
H.B. Sodavadiya*, V.R. Naik and S.D. Chaudhari \\ Department of Agronomy, N.M. College of Agriculture, Navsari Agricultural University, \\ Navsari-396 450, Gujarat, India \\ *Corresponding author
}

\section{A B S T R A C T}

K e y w or d s
Indian bean
(Dolichos
lablab),
Nutrient content
and uptake,
Land
configuration,
Irrigation.
Article Info
Accepted:
04 June 2017
Available Online:
10 August 2017

\section{Keywords}

Indian bean

(Dolichos and uptake,

Land configuration, Irrigation.

Article Info

Accepted: Available Online: 10 August 2017
A field experiment was conducted on clay soil (Vertic ustochrepts) of Soil and Water Management Farm of Navsari Agricultural University, Navsari during rabi season of 2015-16 on "Effect of land configuration, irrigation and INM on quality, nutrient content and uptake of Indian bean (var. GNIB -21)". In all, twelve treatment combinations consisting of two levels each of land configuration (L1: Raised bed and L2: Flatbed), irrigation (I1: 0.4 and I2: $0.6 \mathrm{IW} / \mathrm{CPE}$ ratio) and three levels of integrated nutrient management $[\mathrm{F} 1=100 \% \mathrm{RDF}, \mathrm{F} 2=75 \% \mathrm{RDF}+5 \mathrm{t} \mathrm{BC} / \mathrm{ha}+$ bio fertilizer (Rhizobium + $\mathrm{PSB})$ and $\mathrm{F} 3=50 \% \mathrm{RDF}+5 \mathrm{t} \mathrm{BC} /$ ha + bio fertilizer (Rhizobium + PSB) $]$ were tried in split plot design with three replications. The results revealed that protein content as well as nutrients content in seed and stover was not influenced significantly due to main effect of land configuration, irrigation and INM as well as their interactive effects. While the protein yield in seed was affected significantly due to land configuration treatment. Significantly higher protein yield in seed and stover were recorded with raised bed configuration as compared to flat bed sowing. In case of INM treatment, only protein yield in seed was affected significantly. Here, treatment $F_{2}$ and $F_{3}$ remained at par with each other and both were significantly superior over treatment $F_{1}$. Uptake of all the nutrients by seed as well as stover was significantly higher in raised bed configuration in comparison to control. Irrigation scheduling did not alter the nutrient uptake by seed and stover. In case of INM treatments, only uptake of nutrient by seed was influenced significantly, in all the cases treatment $\mathrm{F}_{2}$ and $\mathrm{F}_{3}$ remained at par with each other and both were performed better than treatment $\mathrm{F}_{1}$.

\section{Introduction}

The Indian bean (Dolichos lablab L.) belongs to the family Leguminosae and considered as nutritious vegetables as they contain high amount of vegetable protein, besides carbohydrates and vitamins. The crop has multipurpose use. The green tender pods are used as vegetable and also as the dry seeds. It is one of the excellent pod vegetable crops grown in India. The green pods and tender leaves are popular vegetables. Its fresh green pod contain $86.1 \%$ moisture, $3.8 \%$ protein, $6.7 \%$ carbohydrates, $0.75 \%$ fat, $0.9 \%$ mineral matter and vitamin-A 312 I.U. (Singh et al. 2004). In south Gujarat, It is mostly grown during rabi season in field vacated by kharif crops like paddy. Recommended / cultivated field bean varieties like G.wal-1 and N-wal125-36 and local vegetable purpose varieties 
like katargram and kapasia are grown by the farmers. Apart from there, new variety GNIB -21 found most promising for vegetable purpose due to its short stature plants, early picking and short duration. It became popular among the farmer of South Gujarat due to it's suitability as intercrop also, to improve quality of any crops, timely and proper management practices has very much importance. Low productivity of crop as well as poor quality are mainly due to adoption of improper agrotechniques such as method of sowing, irrigation and nutrient management. Hence, to study the effect of different agrotechniques on quality and nutrient content and uptake by Indian bean, present experiment was planned.

\section{Materials and Methods}

The experiment was conducted on Soil and Water Management Research Unit Farm (SWMRU), Navsari Agricultural University, Navsari during rabi season of 2015-16. These soils are locally known as "deep black soil". The colour of dry soil is dark brown and textured clay with medium in organic carbon $(0.52 \%)$, low in available nitrogen (67.0 $\mathrm{kg} / \mathrm{ha})$, high in phosphorus (186.1 kg/ha) and high in available potassium $(588.1 \mathrm{~kg} / \mathrm{ha})$. Treatment combinations consisting of two levels each of land configuration $\left(\mathrm{L}_{1}\right.$ : Raised bed and $\mathrm{L}_{2}$ : Flatbed), irrigation $\left(\mathrm{I}_{1}: 0.4\right.$ and $\mathrm{I}_{2}$ : $0.6 \mathrm{IW} / \mathrm{CPE}$ ratio) and three levels of integrated nutrient management $\left(\mathrm{F}_{1}=100 \%\right.$ RDF (20:40:00 NPK kg/ha), $\mathrm{F}_{2}=75 \% \mathrm{RDF}+$ $5 \mathrm{tBC} / \mathrm{ha}+$ bio fertilizer (Rhizobium $+\mathrm{PSB}$ ) and $\mathrm{F}_{3}=50 \% \mathrm{RDF}+5 \mathrm{t} \mathrm{BC} / \mathrm{ha}+$ bio fertilizer
(Rhizobium + PSB) ) were tried in split plot design where land configuration and irrigation schedules were allocated to main plots while integrated nutrient management system were assigned to sub plots and replicated thrice. Indian bean cultivar GNIB-21 was sown in $6^{\text {th }}$ November with aforesaid treatment and their combinations with $45 \times 10 \mathrm{~cm}$ (For $\mathrm{L}_{1}$ ) \& $30 \times 10 \mathrm{~cm}\left(\right.$ For $\left.\mathrm{L}_{2}\right)$ row to row and plant to plant spacing. Crop was fertilized and irrigated as per treatments. For $\mathrm{L}_{1}$ and $\mathrm{L}_{2}$ treatments depth of irrigation was kept $60 \mathrm{~mm}$ and $40 \mathrm{~mm}$, respectively. First common irrigation at $80 \mathrm{~mm}$ depth was given to all the treatments at the time of sowing for uniform germination. Thinning and weeding were done as per requirement and harvesting was done when crop was fully matured . Random samples of seed and stover each net plot area were collected for chemical analysis . The samples were oven dried at $60^{\circ} \mathrm{C}$ for 24 hours, powdered by mechanical grinder and analyzed for respective nutrient content using following procedures.

\begin{tabular}{|l|l|l|}
\hline Particular & Procedure used & Reference \\
\hline $\begin{array}{l}\text { Nitrogen } \\
(\%)\end{array}$ & $\begin{array}{l}\text { Modified } \\
\text { Kjeldahl's } \\
\text { method }\end{array}$ & $\begin{array}{l}\text { Jackson } \\
(1973)\end{array}$ \\
\hline $\begin{array}{l}\text { Phosphorus } \\
(\%)\end{array}$ & $\begin{array}{l}\text { Vanadomolybdo } \\
\text { phosphoric acid } \\
\text { yellow color } \\
\text { method }\end{array}$ & $\begin{array}{l}\text { Jackson } \\
(1973)\end{array}$ \\
\hline $\begin{array}{l}\text { Potassium } \\
(\%)\end{array}$ & $\begin{array}{l}\text { Flame } \\
\text { photometric } \\
\text { method }\end{array}$ & $\begin{array}{l}\text { Jackson } \\
(1973)\end{array}$ \\
\hline
\end{tabular}

Nutrient uptake/protein yield $=$ $\left(\mathrm{kg} \mathrm{ha}^{-1}\right)$

Protein content in the seed and stover were computed by multiplying nitrogen content with factor 6.5. The uptake values of seed and

Content (\%) X Dry matter yield

100 stover of macronutrients as well as protein yield were calculated by using following formula and were expressed as $\mathrm{kg} \mathrm{ha}^{-1}$ and was 
subjected to statistical analysis as per method suggested by Panse and Sukhatme (1967).

\section{Results and Discussion}

\section{Effect of different treatment on quality}

Protein content in seed and stover were not altered due to main as well as interactive effect of land configuration, irrigation and INM (Table 1). While protein yield in seed was affected significantly due to individual effect of land configuration and INM as well as interactive effect of land configuration $\times$ irrigation (Fig. 1). Raised bed sowing registered significantly higher protein yield (233 kg/ha) in seed as compared to flatbed sowing. Raised bed configuration provides good aeration and drainage condition that might stimulate root growth and thereby increase uptake of $\mathrm{N}$ and ultimately resulted into higher protein yield. In case of INM treatments, treatment $\mathrm{F}_{2}$ and $\mathrm{F}_{3}$ with 234 and $224 \mathrm{~kg} / \mathrm{ha}$ of protein yield in seed, respectively remained at par with each other and both were significantly superior over treatment $F_{1}$, which registered $192 \mathrm{~kg} / \mathrm{ha}$ of protein yield in seed. In $F_{2}$ and $F_{3}$ treatment bio compost and biofertilizer were used that might have increased the $\mathrm{N}$ uptake and ultimately protein yield also increased. With respect to protein yield in stover, only the individual effect of land configuration and interaction effect of land configuration $\times$ irrigation were found to be significant. Between to land configuration treatment raised bed sowing $(566 \mathrm{~kg} / \mathrm{ha})$ performed better than flatbed sowing (453 kg/ha). In case $\mathrm{L} \times \mathrm{I}$ interaction treatment $\mathrm{L}_{2} \times \mathrm{I}_{1}$ (Raised bed $\times 0.4 \mathrm{IW} / \mathrm{CPE}$ ratio) out yielded rest of the treatment by registering significantly higher protein yield of 250 and $627 \mathrm{~kg} / \mathrm{ha}$, in seeds and stover of Indian bean, respectively. Here, crop was sown on raised bed and irrigation was given at $0.4 \mathrm{IW} / \mathrm{CPE}$ ratio that met the requirement of Indian bean. Shinde et al., (2000) from Rahuri also reported higher protein yield in chickpea with ridge and furrow method of sowing and Patel et al., (2009) from South Gujarat in chickpea with ridges and furrow method of sowing found significantly better with respect to seed and straw yield with better quality of chickpea.

\section{Effect of different treatments on nutrient content and uptake of nutrients}

\section{Effect of land configuration}

The content of $\mathrm{N}, \mathrm{P}$ and $\mathrm{K}$ were separately determined from seed and stover of Indian bean. The effect of land configuration on N, P and $\mathrm{K}$ content in stover as well as in seed of Indian bean were not found to be significant, whereas, uptake of all the three nutrients found to be significant for seed and stover (Table 2). In all the cases raised bed configuration found significantly superior over flatbed sowing. The seed as well as stover yield were significantly higher under raised bed configuration in comparison to flatbed sowing (Table 2). This implies that the nutrient uptake by seed and stover were governed by biomass yield rather than their content. On an average, increase in uptake of $\mathrm{N}$ by seed and stover with $\mathrm{L}_{2}$ treatment were of the order of 14.01 and 19.95 percent respectively over flatbed sowing. The corresponding percentage $\mathrm{P}$ was 16.52 and $\mathrm{K}$ was 15.92 .

\section{Effect of irrigation}

The main effect of irrigation was not pronounced on nutrient content as well as uptake by Indian bean. The biomass yield as well as nutrient content were not found to be significant. Ultimately, the uptake that governs either by content or by biomass yield was also found to be non-significant. 
Table.1 Effect of land configuration, irrigation and INM on protein content (\%) and protein yield (kg/ha) of Indian bean

\begin{tabular}{|c|c|c|c|c|}
\hline \multirow[t]{2}{*}{ Treatment } & \multicolumn{2}{|c|}{$\begin{array}{l}\text { Protein content } \\
\qquad(\%)\end{array}$} & \multicolumn{2}{|c|}{$\begin{array}{l}\text { Protein yield } \\
(\mathrm{kg} / \mathrm{ha})\end{array}$} \\
\hline & Seed & Stover & Seed & Stover \\
\hline \multicolumn{5}{|l|}{ Main plot } \\
\hline \multicolumn{5}{|l|}{ A. Land configuration } \\
\hline $\mathrm{L}_{1}=$ flat bed & 24 & 14 & 200 & 453 \\
\hline $\mathrm{L}_{2}=$ Raised bed & 24 & 15 & 233 & 566 \\
\hline S. Em. \pm & 0.31 & 0.40 & 4.47 & 21.85 \\
\hline C.D. at $5 \%$ & NS & NS & 15.49 & 75.62 \\
\hline \multicolumn{5}{|l|}{ B. Irrigation } \\
\hline $\mathrm{I}_{1}=0.4 \mathrm{IW} / \mathrm{CPE}$ & 25 & 15 & 219 & 525 \\
\hline $\mathrm{I}_{2}=0.6 \mathrm{IW} / \mathrm{CPE}$ & 24 & 14 & 214 & 493 \\
\hline S. Em. \pm & 0.31 & 0.40 & 4.47 & 21.85 \\
\hline C.D. at $5 \%$ & NS & NS & NS & NS \\
\hline CV\% & 5.37 & 11.88 & 8.77 & 18.21 \\
\hline \multicolumn{5}{|l|}{ Sub plot } \\
\hline \multicolumn{5}{|l|}{ Integrated Nutrient Management } \\
\hline $\mathrm{F}_{1}=100 \% \mathrm{RDF}(20: 40: 00 \mathrm{NPK} \mathrm{kg} / \mathrm{ha})$ & 24 & 14 & 192 & 470 \\
\hline $\begin{array}{l}\mathrm{F}_{2}=75 \% \mathrm{RDF}+5 \mathrm{t} \mathrm{BC} / \mathrm{ha}+\text { bio fertilizer } \\
(\mathrm{PSB}+\mathrm{Rhizobium})\end{array}$ & 24 & 14 & 234 & 524 \\
\hline $\begin{array}{l}\mathrm{F}_{3}=50 \% \mathrm{RDF}+5 \mathrm{t} \mathrm{BC} / \mathrm{ha}+\text { bio fertilizer } \\
(\mathrm{PSB}+\text { Rhizobium })\end{array}$ & 25 & 15 & 224 & 533 \\
\hline S. Em. \pm & 0.38 & 0.39 & 5.58 & 20.97 \\
\hline C.D. at $5 \%$ & NS & NS & 16.75 & NS \\
\hline CV\% & 5.39 & 9.53 & 8.94 & 14.27 \\
\hline Significant interaction & - & - & $\mathrm{L} \times \mathrm{I}$ & $\mathrm{L} \times \mathrm{I}$ \\
\hline
\end{tabular}


Table.2 Effect of land configuration, irrigation and INM on N, P and K content and uptake in stover and seed of Indian bean

\begin{tabular}{|c|c|c|c|c|c|c|c|c|c|c|c|c|c|c|}
\hline \multirow[t]{2}{*}{ Treatment } & \multirow[t]{2}{*}{$\begin{array}{c}\text { Seed yield } \\
\text { (kg/ha) }\end{array}$} & \multirow{2}{*}{$\begin{array}{c}\text { Stover } \\
\text { yield } \\
\text { (kg/ha) }\end{array}$} & \multicolumn{2}{|c|}{$\begin{array}{c}\text { N content } \\
(\%)\end{array}$} & \multicolumn{2}{|c|}{$\begin{array}{c}P \text { content } \\
(\%)\end{array}$} & \multicolumn{2}{|c|}{$\begin{array}{c}\text { K content } \\
(\%)\end{array}$} & \multicolumn{2}{|c|}{$\begin{array}{c}\text { N uptake } \\
\text { (kg/ha) }\end{array}$} & \multicolumn{2}{|c|}{$\begin{array}{c}\text { P uptake } \\
\text { (kg/ha) }\end{array}$} & \multicolumn{2}{|c|}{$\begin{array}{c}\text { K uptake } \\
\text { (kg/ha) }\end{array}$} \\
\hline & & & Stover & Seed & Stover & Seed & Stover & Seed & Stover & Seed & Stover & Seed & Stover & Seed \\
\hline \multicolumn{15}{|l|}{ Main plot } \\
\hline \multicolumn{15}{|c|}{ A. Land configuration } \\
\hline $\mathrm{L}_{1}=$ flat bed & 820 & 3344 & 2.17 & 3.92 & 0.22 & 0.50 & 2.04 & 0.11 & 72.44 & 32.03 & 7.39 & 4.07 & 68.54 & 0.92 \\
\hline $\mathrm{L}_{2}=$ Raised bed & 954 & 3779 & 2.39 & 3.90 & 0.23 & 0.50 & 2.16 & 0.11 & 90.49 & 37.25 & 8.58 & 4.79 & 81.53 & 1.08 \\
\hline S. Em. \pm & 15 & 100 & 0.06 & 0.05 & 0.006 & 0.008 & 0.05 & 0.001 & 3.50 & 0.72 & 0.24 & 0.09 & 1.39 & 0.02 \\
\hline C.D. at $5 \%$ & 51 & 345 & NS & $\mathrm{NS}$ & NS & $\mathrm{NS}$ & NS & NS & 12.10 & 2.48 & 0.83 & 0.30 & 4.80 & 0.06 \\
\hline \multicolumn{15}{|l|}{ B. Irrigation } \\
\hline $\mathrm{I}_{1}=0.4 \mathrm{IW} / \mathrm{CPE}$ & 886 & 3591 & 2.32 & 3.96 & 0.23 & 0.50 & 2.05 & 0.11 & 84.00 & 35.07 & 8.14 & 4.41 & 74.23 & 1.01 \\
\hline $\mathrm{I}_{2}=0.6 \mathrm{IW} / \mathrm{CPE}$ & 888 & 3532 & 2.24 & 3.86 & 0.22 & 0.50 & 2.15 & 0.11 & 78.93 & 34.21 & 7.83 & 4.45 & 75.84 & 0.99 \\
\hline S. Em. \pm & 15 & 100 & 0.06 & 0.05 & 0.006 & 0.008 & 0.05 & 0.001 & 3.50 & 0.72 & 0.24 & 0.09 & 1.39 & 0.02 \\
\hline C.D. at $5 \%$ & NS & NS & NS & NS & NS & NS & NS & NS & NS & NS & NS & NS & NS & NS \\
\hline $\mathrm{CV} \%$ & 7.11 & 11.88 & 11.88 & 5.37 & 12.25 & 7.19 & 11.01 & 3.09 & 18.21 & 8.77 & 12.80 & 8.37 & 7.84 & 7.78 \\
\hline \multicolumn{15}{|l|}{ Sub plot } \\
\hline \multicolumn{15}{|c|}{ Integrated Nutrient Management } \\
\hline $\begin{array}{l}F_{1}=100 \% R D F \\
(20: 40: 00 \mathrm{NPK} \mathrm{kg} / \mathrm{ha})\end{array}$ & 787 & 3318 & 2.26 & 3.90 & 0.23 & 0.51 & 2.11 & 0.11 & 75.22 & 30.67 & 7.52 & 4.04 & 71.09 & 0.89 \\
\hline $\begin{array}{l}\mathrm{F}_{2}=75 \% \mathrm{RDF}+5 \mathrm{t} \\
\mathrm{BC} / \mathrm{ha}+\text { bio fertilizer } \\
\text { (PSB + Rhizobium ) }\end{array}$ & 966 & 3771 & 2.22 & 3.87 & 0.23 & 0.49 & 2.04 & 0.11 & 83.91 & 37.68 & 8.53 & 4.69 & 76.99 & 1.08 \\
\hline $\begin{array}{l}\mathrm{F}_{3}=50 \% \mathrm{RDF}+5 \mathrm{t} \\
\mathrm{BC} / \mathrm{ha}+\text { bio fertilizer } \\
(\mathrm{PSB}+\text { Rhizobium })\end{array}$ & 908 & 3596 & 2.36 & 3.96 & 0.22 & 0.50 & 2.14 & 0.11 & 85.27 & 35.87 & 7.90 & 4.56 & 77.02 & 1.03 \\
\hline S. Em. \pm & 17 & 105 & 0.06 & 0.06 & 0.010 & 0.01 & 0.09 & 0.001 & 3.36 & 0.89 & 0.41 & 0.13 & 4.26 & 0.02 \\
\hline C.D. at $5 \%$ & 50 & 315 & NS & NS & NS & NS & NS & NS & NS & 2.68 & NS & 0.40 & NS & 0.07 \\
\hline $\mathrm{CV} \%$ & 6.58 & 10.23 & 9.53 & 5.39 & 15.82 & 9.32 & 14.47 & 3.79 & 14.27 & 8.94 & 17.93 & $\begin{array}{c}10.5 \\
5\end{array}$ & 19.67 & 7.93 \\
\hline Significant Interaction & $\mathrm{L} \times \mathrm{I}$ & $\mathrm{L} \times \mathrm{I}$ & - & - & - & - & - & - & $\mathrm{L} \times \mathrm{I}$ & $\mathrm{L} \times \mathrm{I}$ & NS & $\mathrm{L} \times \mathrm{I}$ & $\mathrm{L} \times \mathrm{I}$ & $\mathrm{L} \times \mathrm{I}$ \\
\hline
\end{tabular}


Fig.1 Protein yield (kg/ha) in stover and seed influenced by interactive effect of land configuration and irrigation
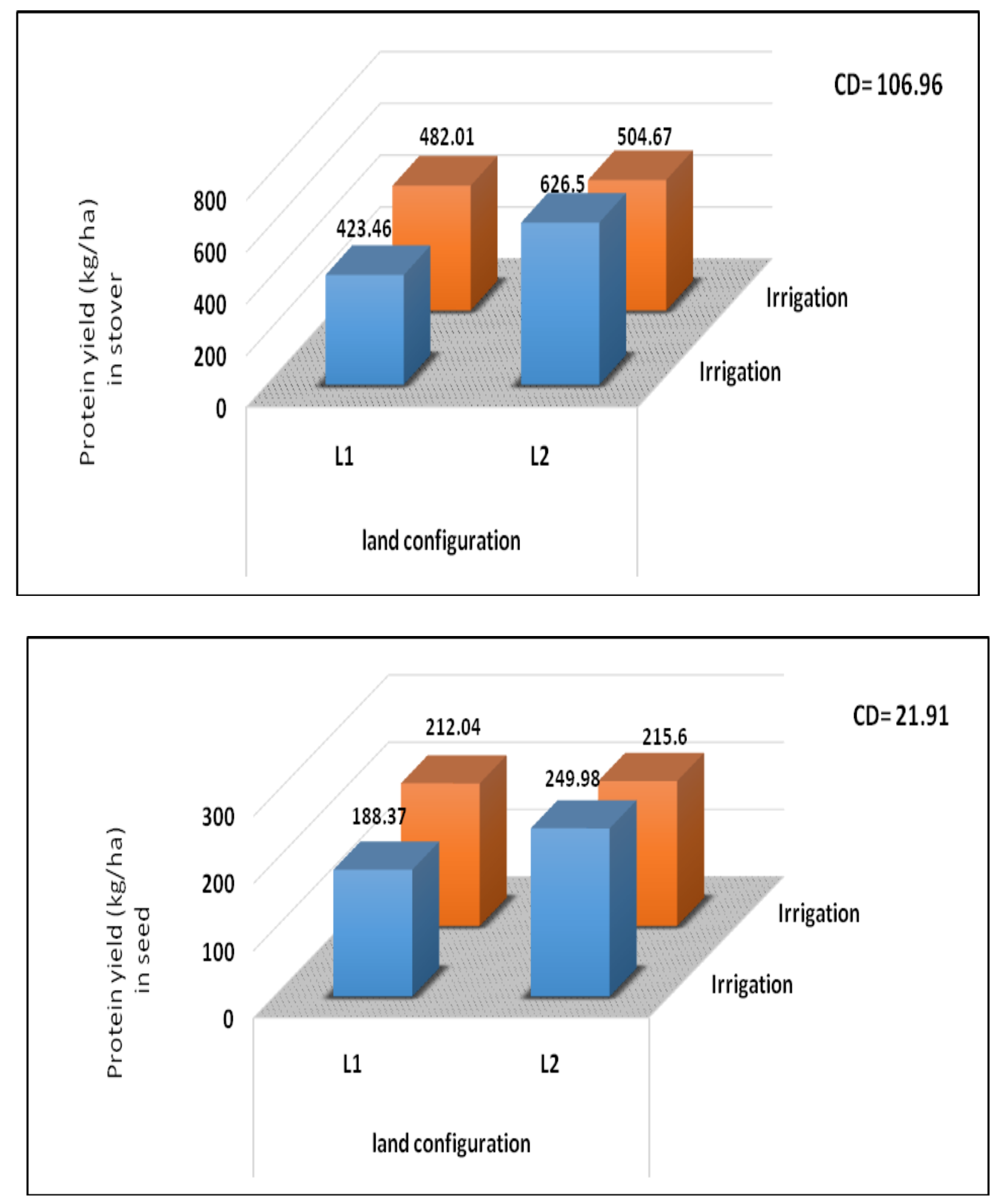
Fig.2 Seed and stover yield (kg/ha) influenced by interactive effect of land configuration and irrigation

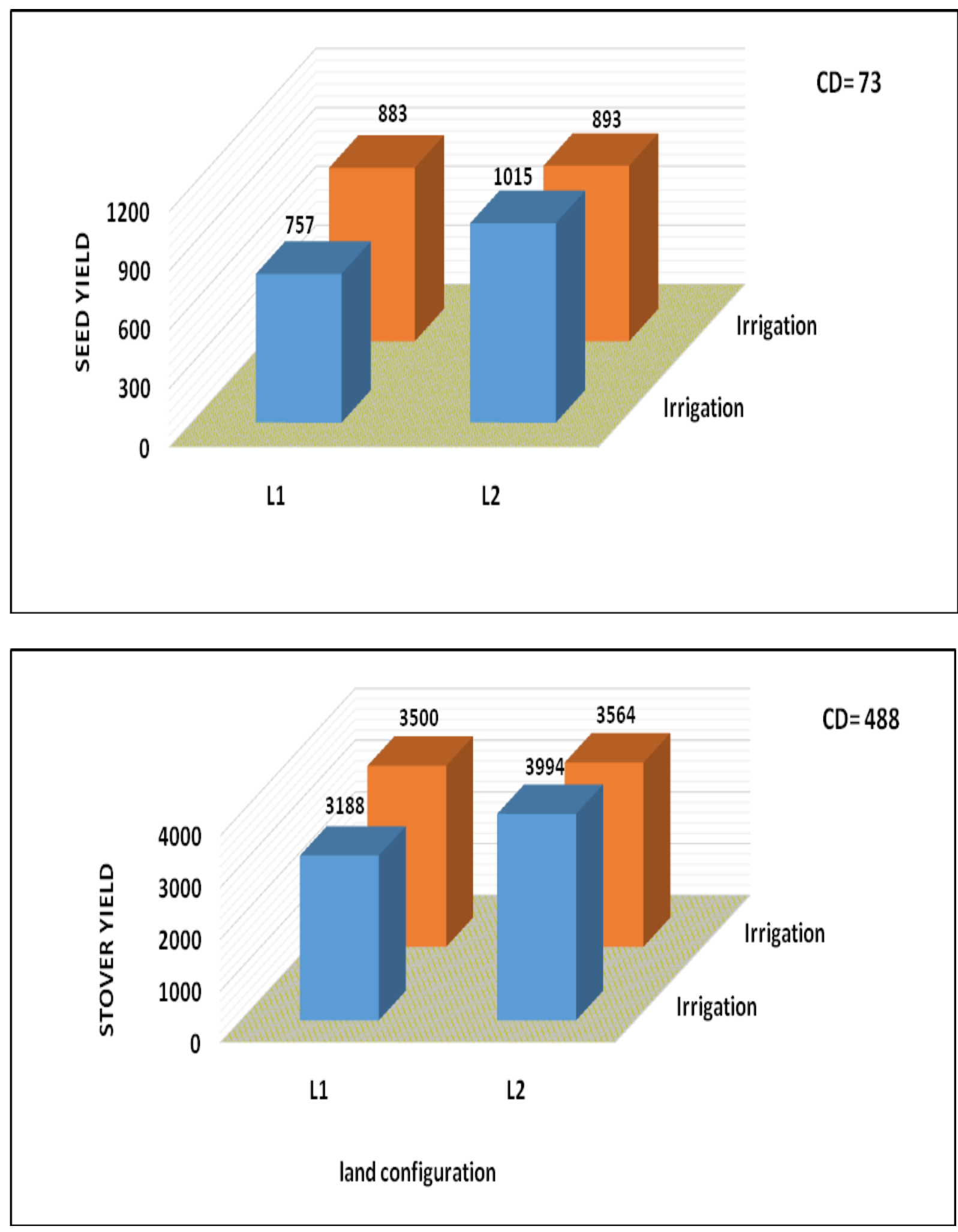


Fig.3 $\mathrm{N}$ uptake $(\mathrm{kg} / \mathrm{ha})$ in stover and seed influenced by interactive effect of land configuration and irrigation
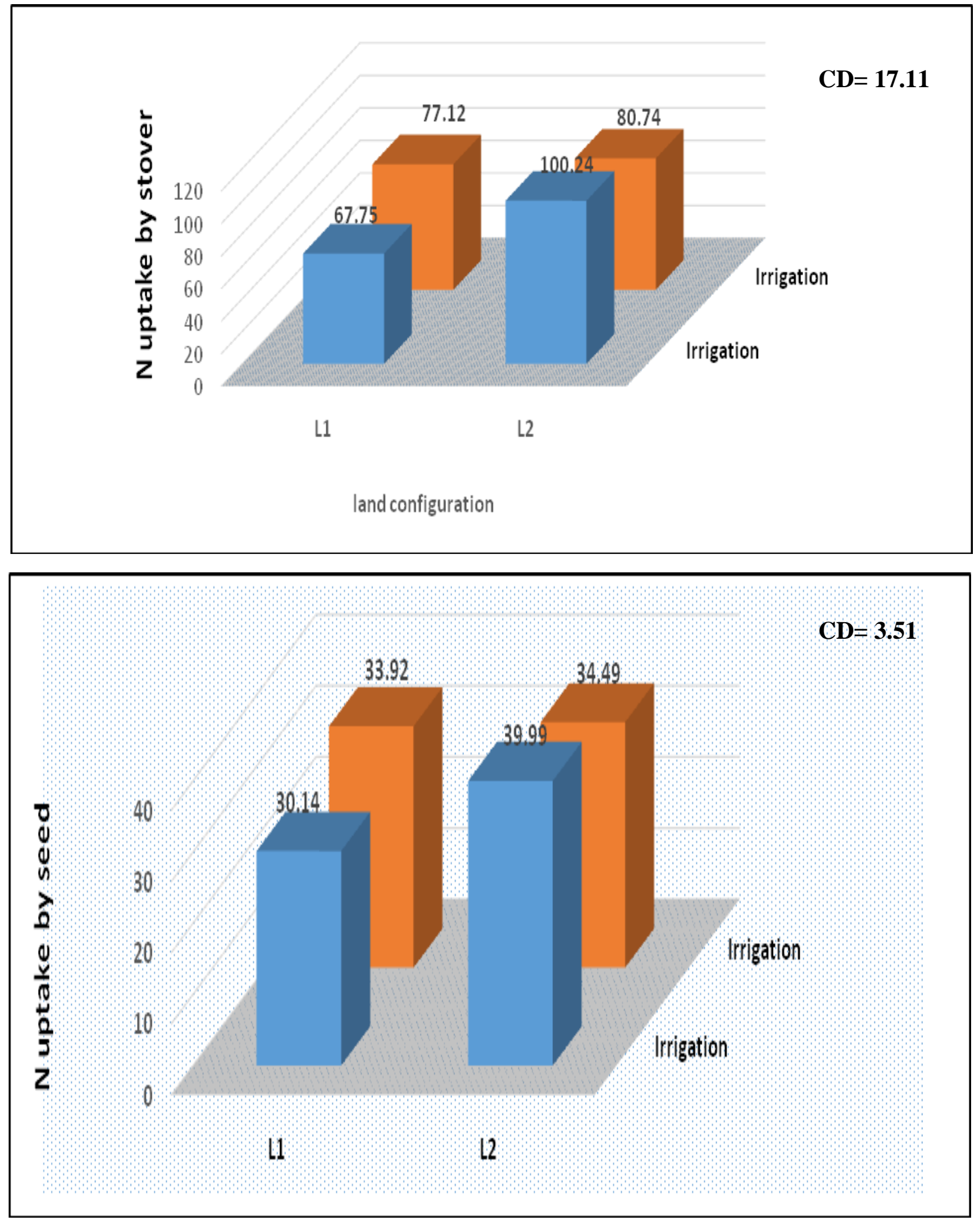
Fig.4 P uptake (kg/ha) in seed influenced by interactive effect of land configuration and irrigation

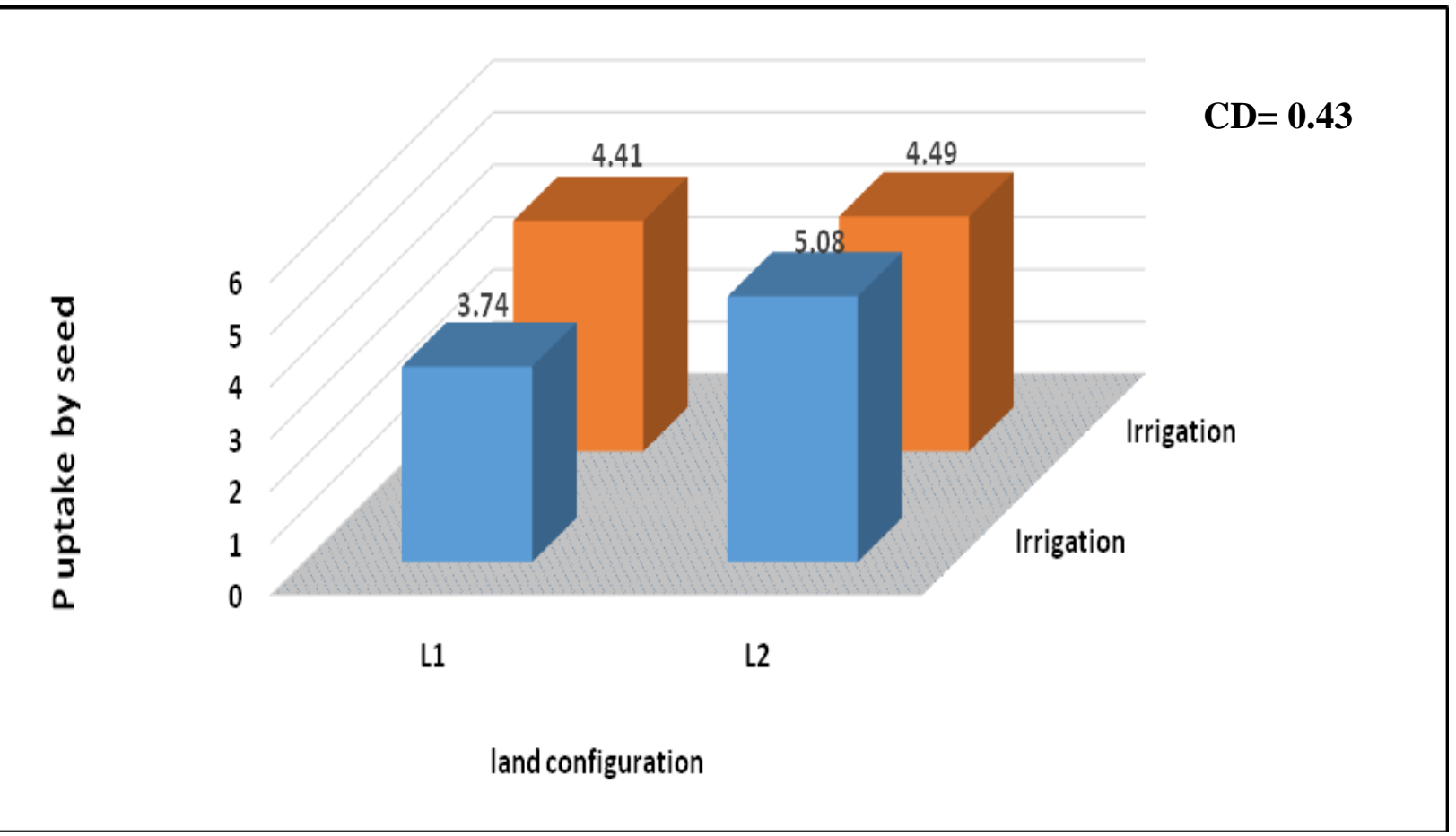

Fig.5 K uptake (kg/ha) in stover and seed influenced by interactive effect of land configuration and irrigation

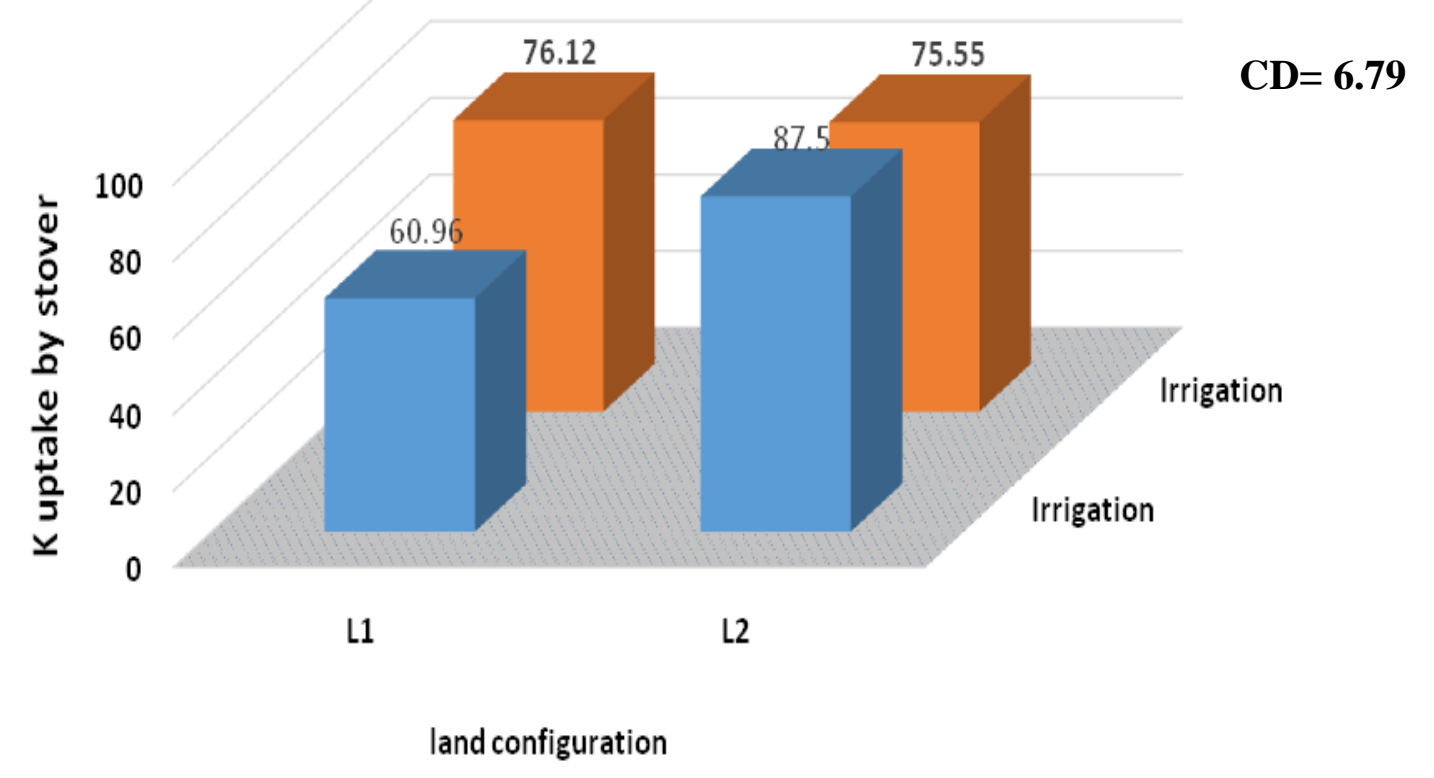




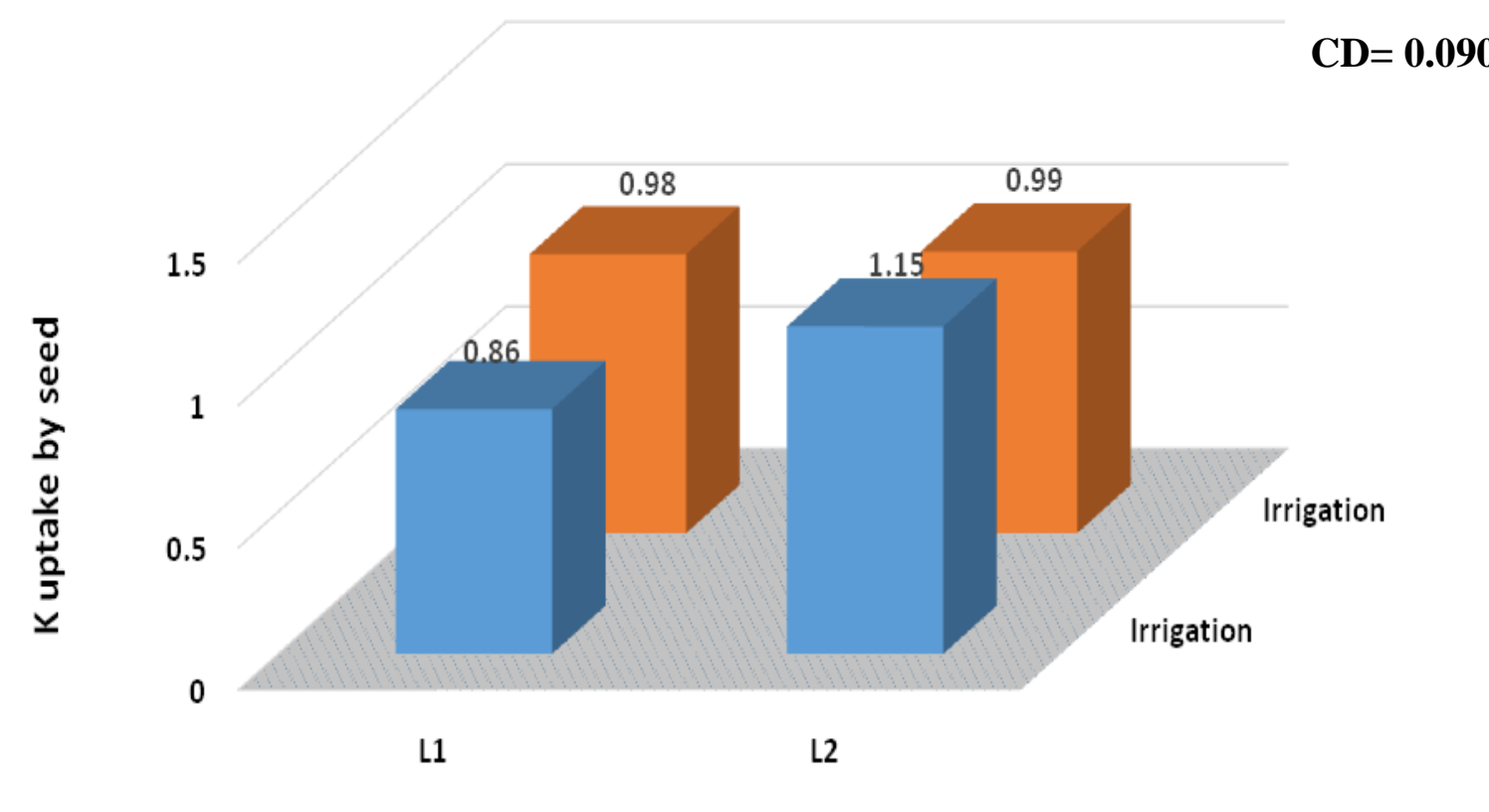

land configuration

\section{Effect of INM}

Nutrient content in seed and stover were not affected significantly due to individual effect of INM but uptake of all the nutrients by seed were influenced significant due to INM effect. In all the cases, treatment $F_{2}$ and $F_{3}$ remained at par with each other and both were recorded significantly higher uptake of nutrient than $F_{1}$. In $F_{2}$ and $F_{3}$ treatments biocompost and biofertilizer were applied, while in $F_{1}$ treatment only chemical fertilizers were used. This also implies that addition of organics and bio fertilizer might have improved nutrient availability and subsequently absorbed by plant and translocated to seeds.Singh et al., (2007) in soybean, Wagadre et al., (2010) in green gram.

\section{Interaction effect}

Nutrient content in seed and stover were not influenced significantly due to any of the interaction. But the uptake of all the nutrients by seed as well as stover was influenced significantly due to $\mathrm{L} \times \mathrm{I}$ interaction except $\mathrm{K}$ uptake by stover. In all the cases treatment $\mathrm{L}_{2} \mathrm{I}_{1}$ registered higher uptake of nutrients by seed and stover (fig 3, $4 \& 5$ ). Here, also the seed as well as stover yield were significantly higher in $\mathrm{L}_{2} \mathrm{I}_{1}$ treatment (fig 2). So that the uptake of nutrient were governed by biomass yield and ultimately higher uptake were recorded with $\mathrm{L}_{2} \mathrm{I}_{1}$ treatment.

It can be concluded from the results that for getting higher protein yield in seed and stover of Indian bean as well as for better utilization of nutrients, the crop should be sown on raised bed and irrigated at $0.4 \mathrm{IW} / \mathrm{CPE}$ ratio (Four irrigation at an interval at 19 days) along with adoption of integrated nutrient management system.

\section{References}

Jackson, M.L. 1973. "Soil Chemical Analysis". Prentice Hall of India Pvt. Ltd. New Delhi. Pp. 183-192.

Panse, V.G. and Sukhatme, P.V. 1967. Statistical methods for agricultural workers. ICAR, New Delhi. Pp. 187-197. 
Patel, K.B., Tandel, Y.N. and Arvadia, M.K. 2009. Effect of irrigation and land configuration on growth, yield and quality of chickpea [Cier arietinum (L.)] under vertisol of South Gujarat. Int. J. Agric. Sci., 5(1): 295-296.

Shinde, S.H., Thakur, N.T. and Bhilare. 2000. Effect of field lay outs and fertilizer levels on productivity of chickpea. $J$. Maharashtra Agri. Univ., 25(1): 76-77.

Singh, K.J., Singh, G., Dhillon, S.S. and Walia, S.S. 2007. Studied on bed planting of ssummer moong for judicious use of phosphorus and irrigation water. Crop Res., 33(1,2\&3): 68-77.

Singh, N.P., Bhardwaj, A.K. and Kumar, A. 2004. Modern technology on vegetables production, pp: 49-50.

Wagadre, N., Patel, M.V. and Patel, H.K. 2010. Response of summer green gram (Vigna radiata L.) to vermicompost and phosphorus with and without PSB inoculation. State level seminar on organic farming, Navsari, Gujarat. pp. 111-114.

\section{How to cite this article:}

Sodavadiya, H.B., V.R. Naik and Chaudhari, S.D. 2017. Effect of Land Configuration, Irrigation and INM on Quality, Nutrient Content and Uptake of Indian Bean (var. GNIB-21). Int.J.Curr.Microbiol.App.Sci. 6(8): 527-537. doi: https://doi.org/10.20546/ijcmas.2017.608.068 